\title{
Preliminary Phytochemical Screening and TLC Analysis of Argemone mexicana
}

\author{
Rohit Singh $^{1 *}$, Neelesh Chaubey ${ }^{1}$, Rajeev Kumar Mishra ${ }^{1}$ \\ ${ }^{1}$ Sri Satya Sai University of Technology and Medical Science, Sehore (M.P) India
}

DOI: $10.36348 /$ sijtcm.2021.v04i02.002 $\quad$ | Received: 08.02.2021 | Accepted: 20.02.2021 | Published: 26.02 .2021

*Corresponding author: Rohit Singh

\section{Abstract}

Medicinal plants play a vital role to preserve human health. The genus Argemone consists of herbs, that are widespread in all over India and represents highly valuable plant species having therapeutic and nutraceutical importance. Genetic variation is essential for long term survival of species and it is a critical feature in conservation. Argemone mexicana (Papaveraceae) also known as Ghamoya. Traditionally the plants used the world for the treatment of several ailments including tumors, warts, skin diseases, inflammations, rheumatism, jaundice, leprosy, microbial infections, and malaria. It is an exotic weed indigenous to South America. In the present study an attempt has been made to assess the preliminary phytochemical screening and TLC profile of various leaves extract of A.mexicana.

Keywords: Argemone mexicana, phytochemical screening \& TLC profile.

Copyright (C) 2021 The Author(s): This is an open-access article distributed under the terms of the Creative Commons Attribution 4.0 International License (CC BY-NC 4.0) which permits unrestricted use, distribution, and reproduction in any medium for non-commercial use provided the original author and source are credited.

\section{INTRODUCTION}

India which is land of one of the oldest and eminent civilization [1]. Plants has been appropriate source of medicines for past era. These medicines primarily took the form of crude drugs [2]. Medicinal plants play a vital role to preserve human health [3]. India is well recognized as the "Emporium of Medicinal Plants". Herbal drugs play an important role in health care programs chiefly in developing countries. Ancient Indian literature incorporates a extremely broad definition of medicinal plants to be potential sources of medicinal substances [4, 5]. Argemone Mexicana (Papaveraceae) as well known as Ghamoya is an alien weed indigenous to South America but now it has been widely distributed in many tropical and sub-tropical countries [6].

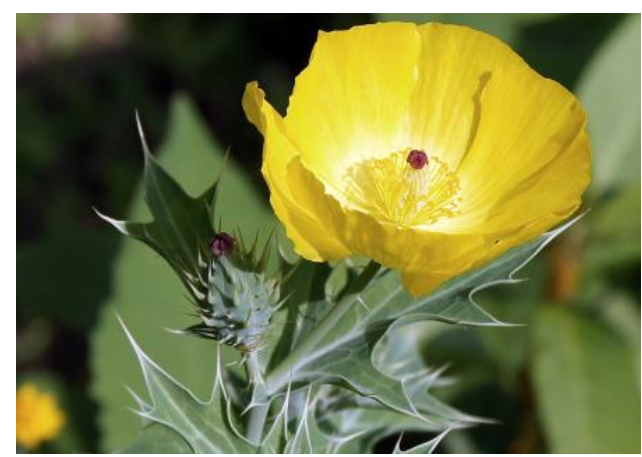

Argemone Mexicana

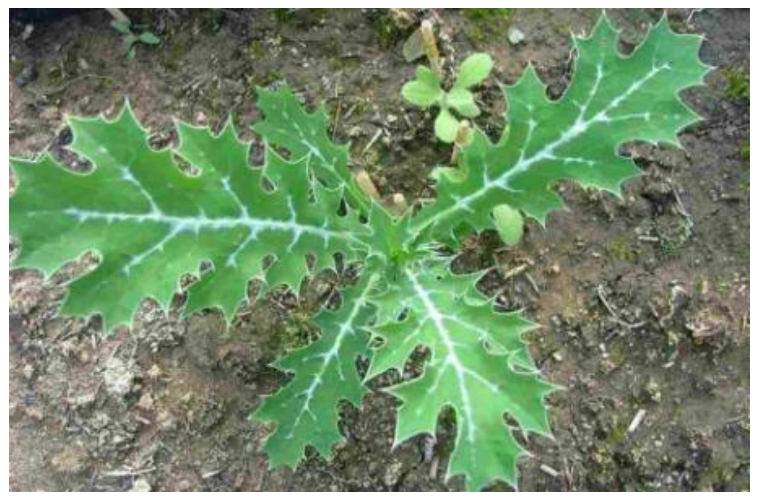

Argemone Mexicana leaves

It is commonly found everywhere by roadsides and fields in India. It is an erect prickly annual herb of about $1 \mathrm{~m}$ high; leaves are usually 5 to $11 \mathrm{~cm}$ long, and more or less blotched with green and white, glaucous broad at the base, half-clasping the stem prominently sinuate-lobed, and spiny [7]. The flowers become 4 to $5 \mathrm{~cm}$ in diameter, and are terminal, yellow, and scentless. The capsule is spiny, obovate or elliptic-oblong, and about $3 \mathrm{~cm}$ in length. The seeds are spherical, shining, and black and pitted [8]. 


\begin{tabular}{|l|l|}
\hline Traditionally uses [9, 10] & \multicolumn{1}{c|}{ Pharmacological uses [11] } \\
\hline Potent diuretic agent & Bitter, acrid, cooling \& purgative. \\
Anti-anti-helmintic & Expectorant, aphrodisiac, emetic, anodyne, anti-helmintic, antipyretic, ophthalmic, \\
Anti-inflammatory & stomachic and sedative. \\
Wound healing & It cures leprosy, skin - diseases, inflammation and bilious fevers. Roots are useful in \\
Anti-bacterial & guinea-worm infestation, skin diseases, leprosy, pruritus, blennorrhagia, inflammations, \\
Antifungal & all type of poisoning, constipation, flatulence, colic, malarial fever and vestibular \\
& calculus. \\
& The leaves are useful in cough, wounds and ulcers. \\
& Leaves also used in skin diseases. Juice is used to cure opthalmia and opacity of cornea. \\
& Seeds are purgative and sedative. \\
\hline
\end{tabular}

In the present study an attempt has been made to assess the preliminary phytochemical screening and TLC profile of various leaves extract of A.mexicana.

\section{MATERIALS AND METHODS Collection \& Authentication}

Argemone mexicana leaves were collected in the month of April from local region of Sehore district Madhya Pradesh (India). Herbarium specimens were prepared, identification and authenticated.

\section{Preliminary physiochemical screening of plant extracts [12-16] \\ Determination of solvent extractive values}

Determination of water soluble extractive value: $5 \mathrm{~g}$ of the air-dried drug, coarsely powdered were macerated with $100 \mathrm{ml}$ of water in closed flask for 24 hours, shaking frequently during the first 6 hours and allow standing for 18 hours. It was filtered rapidly taking precaution against loss of water, then the filtrate was evaporated $25 \mathrm{ml}$ of the filtrate to dryness in a tared flat-bottomed shallow dish, and dried at $105^{\circ} \mathrm{C}$ then weighed. The percentage of water-soluble extractive with reference to the air dried was calculated.

Determination of alcohol soluble extractive value: $5 \mathrm{gm}$ of the air dried and coarsely powdered drug was macerated with $100 \mathrm{ml}$ of ethanol of the specific strength in a closed flask for 24 hours, shaking frequently during the first 6 hours and allow standing for 18 hours. There after filter rapidly taking precaution against loss of ethanol. Evaporate $25 \mathrm{ml}$ of the filtrate to dryness in a tared flat bottomed shallow dish, dry at $105^{\circ} \mathrm{c}$ and weigh. The percentage of ethanol soluble extractive with reference to the air dried drug has to be calculated.

Determination of moisture content: Moisture is an inevitable component of crude drugs, which must be eliminated as far as practicable. Method of determination of moisture content include the loss on drying, the test for loss on drying determines both water and volatile matter in the crude drug. It can be carried out either by heating at $100^{\circ} \mathrm{C}-105^{\circ} \mathrm{C}$ or in a dessicator over phosphorous pentoxide under atmospheric or reduced pressure at room temperature for specific period of time.

Ash value: Ash value is helpful in determining the quality and purity of a crude drug, especially in the powdered form. On incineration, crude drugs normally leave an ash usually consisting of carbonates, phosphates and silicates of sodium, potassium, calcium and magnesium. The total ash of a crude drug reflects the care taken in its preparation. A higher limit of acidinsoluble ash is imposed, especially in case where silica may be present or when the calcium oxalate content of the drug is very high.

Total ash value Weighed accurately about 2 to $3 \mathrm{~g}$ of the powdered drug in a tared silica crucible. Incinerated at a temperature not exceeding $450{ }^{\circ} \mathrm{C}$ for 4 hr, until free from carbon, cooled and weighed. The percentage of ash with reference to air-dried was calculated following formula.

\section{$\underline{\text { Wt. of total ash }} \times 100$}

Wt. of crude drugs

weighed. Substrate the weight of insoluble matter from the total weight of ash. The difference in weight represented weight of water soluble ash. Calculated the percentage of water soluble ash with reference to the air- dried drug by using the following formula. 
Acid insoluble ash value: Boiled the ash for 5 min with $25 \mathrm{ml}$ of $2 \mathrm{M}$ HCL. Filtered and collected the insoluble matter on an ash less filter paper, washed with hot water and ignited in a tared crucible at a

\section{$\%$ Acid insoluble ash value $=$}

\section{Preliminary qualitative test}

The various leaves extract of A.mexicana was subjected to preliminary qualitative phytochemical investigation. The various tests and reagent used are given below.

\section{Alkaloids \\ Preparation of test solution: The test solution was prepared by dissolving extracts in the dilute hydrochloric acid. \\ Mayer' test: The acidic test solution with Mayer's reagent (Potassium Mercuric iodide) gave cream colored precipitate.}

Hager's test: The acidic test solution with Hager's reagent (Saturated picric acid solution) gave yellow precipitate.

Dragendorff's test: The acidic solution with Dragendorff's reagent (Potassium bismuth iodide) showed reddish brown precipitate.

Wagner's test: The acidic test solution treated with Wagner's reagent (Iodine in potassium iodide) gave brown precipitate.

Tannic acid test: The acidic test solution treated with Tannic acid gave buff colour precipitate.

Picrolonic acid test: Alkaloids gave yellow colour precipitate with picrolonic acid.

\section{Amino acid}

Millon'test: To the test solution add about $2 \mathrm{ml}$ of millon's reagent white precipitate indicates presence of amino acid.

Ninhydrine test: To the test solution add Ninhydrine solution, boil, violet colour indicates presence of amino acid.

\section{Carbohydrates}

Preparation of test solution: The test solution was prepared by dissolving the test extracts with water. Then it was hydrolyzed with 1 volume of $1 \mathrm{~N}-\mathrm{HCL}$ and subjected to following chemical test. temperature not exceeding $450{ }^{\circ} \mathrm{C}$ for $4 \mathrm{~h}$. cooled in a desiccator and weighed. Calculated the percentage of acid insoluble ash with reference to the air -dried drug was calculated by using following formula,

\section{Wt. of acid insoluble ash Wt. of crude drug taken

$$
\times 100
$$

Molisch's test: Test solution with few drops of Molisch's reagent and $2 \mathrm{ml}$ of conc. $\mathrm{H}_{2} \mathrm{So}_{4}$ added slowly from the sides of the test tubes. It showed a purple ring at the junction of two liquids.

Barfoed's test: $1 \mathrm{ml}$ of test solution is heated with $1 \mathrm{ml}$ of Barfoed, $\mathrm{s}$ reagent on water bath, if red cupric oxide is formed, monosaccharide is present. Disaccharides on prolong heating (about $10 \mathrm{~min}$.) may also cause reduction, owing to partial hydrolysis to monosaccharide.

Benedict's test: Test solution treated with Benedict' reagent and after boiling on water bath, it showed reddish brown precipitate.

Fehling's test: The test solution when heated with equal volume of Fehling's A and B solution, gave orange red precipitate, indicating the presence of reducing sugars

\section{Flavonoids}

The flavonoids are all structurally derived from the parent substance called flavones. The flavonoids occur in the free from as well as bound to sugars as glycosides. For this reason, when analyzing flavonoids it is usually better to examine the flavonoids in hydrolyzed plant extracts.

Preparation of test solution: To a small amount of extract added equal volume of $2 \mathrm{M} \mathrm{HCL}$ and heated in a test tube for 30 to $40 \mathrm{~min}$ at $100^{\circ} \mathrm{C}$. The cooled extract was filtered, and extracted with ethyl acetate The ethyl acetate was concentrated to dryness, and used to test for flavonoids.

Shinoda test: Test solution with few fragments of magnesium ribbon and conc. HCL showed pink to magenta red colour. To a small quantity of test solution when lead acetate solution was added, it formed yellow colored precipitate.

Alkaline reagent test: Test solution when treated with sodium hydroxide solution showed increase in the intensity of yellow colour, which becomes colorless on addition of few drops of dilute acid. 


\section{Glycosides}

Preparation of test solution: The test solution was prepared by dissolving extract in the alcohol or hydro- alcoholic solution.

\section{Test for Cardiac glycosides}

Kedde' test: Add one drop of $90 \%$ alcohol and 2 drops of $2 \%$ 3, 5- dinitro benzoic acid in 90\% alcohol. Make alkaline with $20 \%$ sodium hydroxide solution, purple colour is produced. The colour reaction with 3,5- dinitro benzoic acid depends on the presence of $\alpha, \beta$-unsaturated lactones in the aglycone.

Baljet's test: The test solution treated with sodium picrate gave yellow to orange colour.

Raymond's test: Test solution treated with hot methanolic alkali, violet colour is produced.

Bromine water test: Test solution dissolve in bromine water give yellow precipitate.

Keller-killani test for digitoxose: The test solution treated with few drops of $\mathrm{Fecl}_{3}$ solution and mixed, then $\mathrm{H}_{2} \mathrm{So}_{4}$ containing $\mathrm{Fecl}_{3}$ solution was added, it formed two layers. Lower layer reddish brown, upper layer turns bluish green.

Legal's test: Test solution when treated with pyridine (made alkaline by adding sodium nitroprusside solution) gave pink to red colour.

\section{Test for anthraquinone glycosides}

Borntrager's test: Boiled powdered drug with $5 \mathrm{ml}$ of $10 \%$ sulphuric acid for five minutes. Filtered while hot, cooled the filtrate shaken gently with equal volume of benzene. Benzene layer was separated and then treated with half of its volume solution ammonia (10\%). Allowed to separate. The ammonical layer acquired rose pink colour due to presence of anthraquinones.

\section{Proteins}

\section{Preparation of test solution}

The test solution was prepared by dissolving the extract in water.

\section{Millon's test}

Test solution was treated with millon's reagent and heated on a water bath. The proteins were stained red

\section{Biuret test}

Test solution was treated with $40 \%$ sodium hydroxide and dilute copper sulphate solution gave blue colour.

\section{Xanthoproteic test}

Test solution was treated with conc. $\mathrm{HNO}_{3}$ and boiled which gave yellow precipitate.

\section{Modified Borntrager's test}

C-glycosides of anthraquinones require more drastic conditions for hydrolysis. Hydrolysis of the drug was carried out with $5 \mathrm{ml}$ of dilute of $\mathrm{HCL}$ and $5 \mathrm{ml}$ of $5 \%$ solution of $\mathrm{Fecl}_{3}$. For hydrolyzed extract procedure was carried out as described under Borntrager's test.

\section{Test for steroids}

\section{Preparation of test extracts solution}

The extract was refluxed separately with alcoholic solution of potassium hydroxide till complete saponification. The saponified extract was diluted with water and unsaponificable matter was extracted with diethyl ether. The ethereal extract was evaporated and the residue (saponificable matter) was subjected to the following test by dissolving the residue in the chloroform.

\section{Salkowski test}

To the test extract solution add few drops of conc. $\mathrm{H}_{2} \mathrm{SO}_{4}$ shaken and allowed to stand, lower layer turned red indicating the presence of steroids.

\section{Libermann - Burchard test}

The test solution treated with few drops of acetic anhydride and mixed, when conc. $\mathrm{H}_{2} \mathrm{SO}_{4}$ was added from the sides of the test tubes, it showed a brown ring at the junction of the two layers and the upper layers turned green. Added few drops of concentrated $\mathrm{H}_{2} \mathrm{SO}_{4}$. Blue colour appeared.

\section{Sulphur test} it sank it.

Sulphur test when added in to the test solution,

\section{Tannins and phenol compound}

To 2-3 ml of alcoholic or aqueous extract, added few drops of following reagents.

\section{$5 \% \mathrm{Fecl}_{3}$ solution}

Deep blue- black colour

\section{Lead acetate solution}

White precipitate

\section{Bromine water}

Discoloration of bromine water

\section{Acetic acid solution}

Red colour solution

\section{Dilute iodine solution}

\section{Transient red colour}

One drop of $\mathrm{NH}_{4} \mathrm{OH}$, excess $10 \% \quad \mathrm{AgNO}_{3}$ solution. Heated for $20 \mathrm{~min}$ in boiling water bath. White precipitate was observed, then dark silver mirror deposited on wall of test tube. 


\section{Triterpenoids}

Preparation of test extract solution: The test extract solution was prepared by dissolving extract in the chloroform.

Salkowski test: Few drops of concentrated sulphuric acid were added to the test solution, shaken and on standing lower layer turned golden yellow.

\section{Chromatographic techniques}

\section{Thin Layer Chromatography [17-18]}

TLC is simple, inexpensive and quick technique that gives an exact idea about presence of number of chemical constituents present in plant extract. It is also used to identification of compound in an extract when matched with $R_{f}$ of a known compound with $R_{\mathrm{f}}$ of compound in an extract.Ethanolic extract ant its various fractions were subjected to thin layer chromatography to find out the number of phytochemicals present. The details of the procedure were as follows.

\section{Preparation of the plates}

About $25 \mathrm{~g}$ of silica gel $\mathrm{G}$ (adsorbent) was taken in a glass mortar, into this $35 \mathrm{~mL}$ of distilled water added. It was stirred with glass rod till becomes homogeneous and then allowed to swell it for 15 minutes. Then additional $15 \mathrm{~mL}$ of distilled water was added to it with stirring. The suspension obtained was then poured and spreaded immediately on glass slides to form thin layer chromatographic plates.

\section{Drying and storage of plates}

The freshly coated plates were then air dried, then stacked in a drying rack and were heated in an oven for 30 minutes at $110^{\circ} \mathrm{C}$. The activated plates were then kept in a desiccator, till required for further use.

\section{Application of the sample}

For applying test samples on TLC plates, glass capillaries were used. The spots were applied with the help of a fine capillary. The spots of the samples were marked on the top of the plate to know their identity.

\section{Development of chromatogram}

The mobile phase to be used was put into TLC chamber and chamber was allowed to saturate for 30 minutes. After the application of sample solution on TLC plate, it was placed in mobile phase in TLC glass chamber and allowed the mobile phase to move through adsorbent phase upto a sufficient distance. After developing, the plate was observed under UV cabinet (short, long and visible light) to find out separation and detection of compounds.

\section{RESULT AND DISCUSSION}

Phytoconstituent are the natural bioactive compounds found in plants. It works with nutrients and fibers to form an integrated part of defense system against various diseases conditions. They are basically divided into two groups like primary and secondary metabolites, according to their functions in plant metabolism. Primary metabolites consist of common sugars, amino acids, proteins and chlorophyll while alkaloids, terpenoids, flavonoids, tannins etc. contribute as the secondary metabolites. In the present study the physiochemical parameter was determined and result is tabulated in table 1 . The result revealed that the alcohol soluble extractive value found to be more as compared with water soluble extractive (graph 1). Total ash, water-Soluble ash and acid insoluble ash were determined (graph 2). Percentage of extract/fraction obtained of A. mexicana leaves was found in following order: ethanolic extract> Chloroform extract > ethyl acetate (table $2 \&$ graph 3). In present work; different qualitative tests were carried out with the A. mexicana leaves samples after extraction with various solvents. The results of the phytochemical screening revealed the presence of alkaloids, steroids, phenolics, glycosides, but less terpenoids, flavonoids. The phenolics and glycosides were primarily present in the protic, polar solvents. Among the extracts of A. mexicana leaves, high total phenolic content values were found in ethyl acetate and ethanolic extracts. Plant phenolics, in general, are highly effective free radical scavengers and antioxidants. Due to the presence of phenolic compounds, ethyl acetate and ethanol extracts showed higher scavenging ability of the free radicals (on the basis of median inhibitory concentration). The chromatographic analysis was done by TLC. Best result was obtained from ethanolic extract at $\mathrm{CHCl}_{3}$ : Methanol (7:3) solvent system having 7 spots. The Chloroform fraction showed 06 spots at $\mathrm{CHCl}_{3}$ : Methanol (9:1) solvent system. Ethyl acetate fraction of leaves extract showed 04 spots at Toluene: ethyl acetate (9:1). Spots were observed under UV light $(254 \mathrm{~nm})$ and with spraying reagent $10 \%$ sulphuric acid in methanol. The chromatographic fingerprinting revealed presence of phenolic compound in various extracts.

\section{CONCLUSION}

The present study may be useful to supplement information in regard to its characterization and identification of plant. The investigations furnished a set of qualitative phytochemical screening along with TLC fingerprinting profile of A. mexicana leaves extracts. These data can serve as diagnostic tools for establishment of quality standards, authentication and identification of the medicinally significant plant and aid in compiling of a suitable monograph of this. 
Table-1: Physiochemical Parameters

\begin{tabular}{|l|l|l|l|l|l|}
\hline S.No. & \multicolumn{2}{|c|}{ Extractive value } & \multicolumn{3}{c|}{ Ash value } \\
\hline & $\begin{array}{l}\text { Alcohol soluble } \\
\text { extractive } \\
(\% \mathbf{w} / \mathbf{w})\end{array}$ & $\begin{array}{l}\text { Water soluble } \\
\text { extractive }(\% \mathbf{w} / \mathbf{w})\end{array}$ & $\begin{array}{l}\text { Total ash } \\
(\% \mathbf{\%} / \mathbf{w})\end{array}$ & $\begin{array}{l}\text { Acid Insoluble } \\
\text { ash }(\% \mathbf{\%} / \mathbf{w})\end{array}$ & $\begin{array}{l}\text { Water soluble } \\
\text { ash }(\boldsymbol{\%} / \mathbf{w})\end{array}$ \\
\hline 1. & 26.12 & 16.26 & 8.84 & 0.80 & 6.82 \\
\hline
\end{tabular}

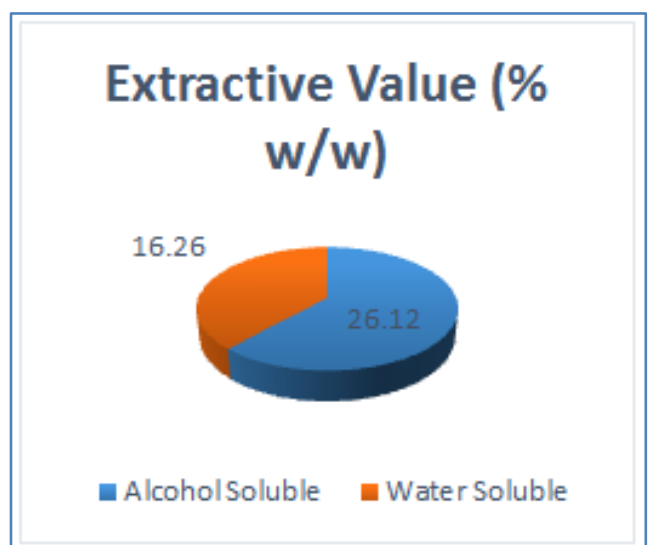

Graph-1:Extractive value (\%w/w)

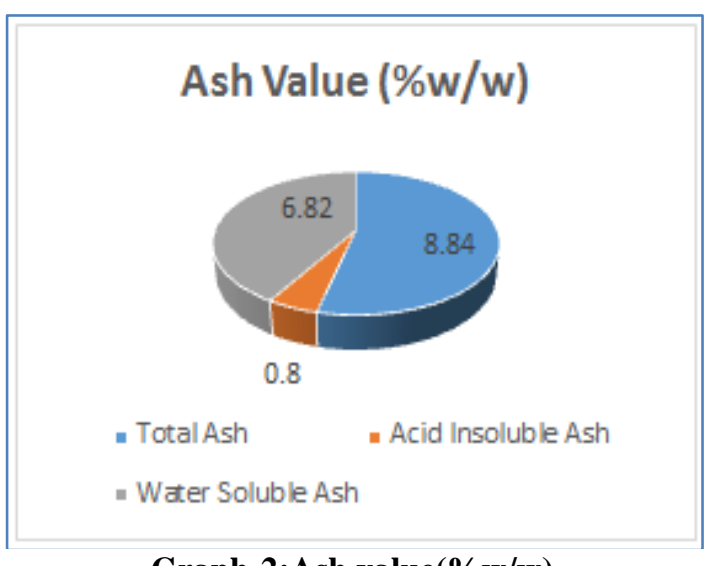

Graph-2:Ash value(\%w/w)

Table-2: Percentage of extract/fraction obtained of Argemone mexicana

\begin{tabular}{|l|l|l|l|l|}
\hline S. No. & Plant Name & $\begin{array}{l}\text { Ethanolic extract } \\
(\% \mathrm{w} / \mathrm{w})\end{array}$ & $\begin{array}{l}\text { Chloroform fraction } \\
(\% \mathrm{w} / \mathrm{w})\end{array}$ & $\begin{array}{l}\text { Ethyl acetate fraction } \\
(\% \mathrm{w} / \mathrm{w})\end{array}$ \\
\hline 1. & $\begin{array}{l}\text { Argemone } \\
\text { mexicana }\end{array}$ & 26.20 & 7.12 & 5.92 \\
\hline
\end{tabular}

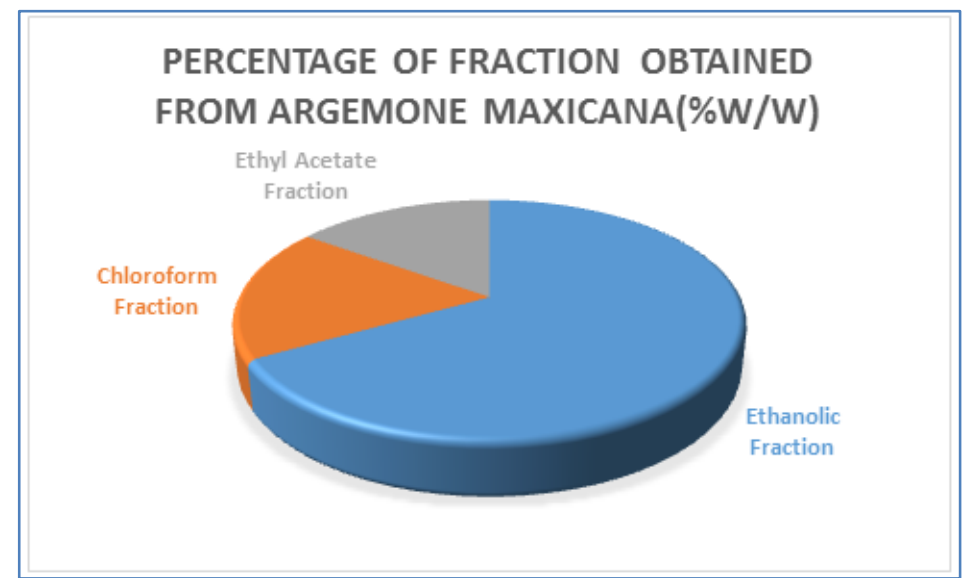

Graph-3:\% of Fraction of extract A.maxicana (\%w/w)

Table-3: Preliminary phytochemical screening of the various extracts of Argemone mexicana

\begin{tabular}{|c|l|c|c|c|}
\hline S. No. & Constituents & Ethanolic extract & Chloroform fraction & Ethyl acetate fraction \\
\hline 1 & Alkaloids & + & - & - \\
\hline 2 & Sterols & + & + & - \\
\hline 3 & Glycosides & - & - & - \\
\hline 4 & Fixed oils and fats & + & - & - \\
\hline 5 & Phenolic compounds & + & - & - \\
\hline 6 & Protein and amino acids & + & + & - \\
\hline 7 & Tannins & - & - & - \\
\hline 8 & Gum and mucilage & + & - & - \\
\hline 9 & Flavonoids & + & + & - \\
\hline 10 & Carbohydrates & - & - & - \\
\hline 11 & Saponins & - & - & - \\
\hline
\end{tabular}

'+ 'Presence,'-'Absence 
Rohit Singh et al., Sch Int J Tradit Complement Med, Feb, 2021; 4(2): 19-25

Table-4: TLC Profile of ethanolic extract and different fractions of Argemone mexicana

\begin{tabular}{|c|c|c|c|c|c|}
\hline S. No. & & $\begin{array}{l}\text { Colour of } \\
\text { extract/fraction }\end{array}$ & Solvent system & $\begin{array}{l}\text { Number of } \\
\text { spots }\end{array}$ & Resolution \\
\hline 1 & \multirow{3}{*}{$\begin{array}{l}\text { Ethanolic } \\
\text { extract }\end{array}$} & \multirow[t]{3}{*}{ Dark green } & Chloroform:Methanol $(9: 1 \mathrm{v} / \mathrm{v})$ & 06 & Excellent \\
\hline 2 & & & Chloroform:Methanol (7:3v/v) & 07 & Good \\
\hline 3 & & & Chloroform:Methanol $(6: 4 \mathrm{v} / \mathrm{v})$ & 03 & good \\
\hline 1 & \multirow{3}{*}{$\begin{array}{l}\text { Chloroform } \\
\text { fraction }\end{array}$} & \multirow[t]{3}{*}{ Dark green } & Chloroform:Methanol $(9: 1 \mathrm{v} / \mathrm{v})$ & 06 & Very Good \\
\hline 2 & & & Chloroform:Methanol $(7: 3 \mathrm{v} / \mathrm{v})$ & 04 & Good \\
\hline 3 & & & Chloroform:Methanol $(6: 4 \mathrm{v} / \mathrm{v})$ & 06 & Good \\
\hline 1 & \multirow{3}{*}{$\begin{array}{l}\text { Ethyl acetate } \\
\text { fraction }\end{array}$} & \multirow[t]{3}{*}{ Brown } & Toluene:Ethyl acetate $(9: 1)$ & 04 & Excellent \\
\hline 2 & & & Toluene:Ethyl acetate $(7: 3)$ & 03 & Very good \\
\hline 3 & & & Toluene:Ethyl acetate $(6: 4)$ & 05 & Excellent \\
\hline
\end{tabular}

Table-5: TLC profile of ethanolic extract of Argemone mexicana in Chloroform: Methanol (9:1 v/v)

\begin{tabular}{|l|l|l|l|}
\hline Spot No. & $\mathbf{R}_{\mathbf{f}}$ value & Colour in UV (254nm) & Colour in sunlight with detecting reagent \\
\hline 1 & 0.20 & Yellow & Yellow \\
\hline 2 & 0.31 & Yellow & Yellow \\
\hline 3 & 0.41 & Pink & Green \\
\hline 4 & 0.45 & Blue & Colourless \\
\hline 5 & 0.51 & Pink & Green \\
\hline 6 & 0.60 & Pink & Green \\
\hline
\end{tabular}

Detecting reagent: Spots were observed under UV light $(254 \mathrm{~nm})$ and with spraying reagent $10 \%$ sulphuric acid in methanol.

\section{REFERENCE}

1. Soni, H. (2011). Preliminary pharmacognostical and phytochemical investigation of Tamarindus indica $\mathrm{L}$. Seed. Int. J. Res. Phytochem.Pharmacol, 1(2), 1-5.

2. Soni, H. (2011). Preliminary phytochemical screening and hplc analysis of flavonoid from methanolic extract of leaves of Annona squamosa. International research journal of pharmacy, 2(5): 242-246.

3. Soni, H., Singhai, A. K., Sharma, S., Nayak, G., \& Swarnkar, P. (2011). Quantification of ascorbic acid in salad components. In IJCPR, 4(1); 43-47.

4. Shweta, S., \& Himesh, S. (2019). Phytopharmacology Profile of Bougainvillea glabra: An Overview. Br J Med Health Res, 6(05).30-38.

5. Soni, H., Sharma, S., Malik, J. K., \& Sarankar, S. K. (2020). Role of healthy food in prevention of neural tube defects: A Review. Saudi J Med Pharm Sci, 6(1), 20.

6. Ibrahim, H. A., \& Ibrahim, H. (2009). Phytochemical screening and toxicity evaluation on the leaves of Argemone mexicana Linn.(Papaveraceae). International Journal of Applied Sciences, 3, 39-43.

7. Chopra, R. N. (1956). Nayar SL Chopra IC Glossary of Indian Medicinal Plants. Council of Scientific and Industrial Research, New Delhi, India, 186-187.

8. Brahmachari, G., Gorai, D., \& Roy, R. (2013). Argemone mexicana: chemical and pharmacological aspects. Revista Brasileira de Farmacognosia, 23(3), 559-575.

9. Anonymous. (2004). In the Wealth of India A Dictionary of Indian Raw Materials and Industrial
Products. Council of Scientific and Industrial Research, New Delhi, I, 86-87.

10. Himesh, S., \& Singhai, A.K. (2012). Recent Update of Botanical For Wound Healing Activity. IRJP, 3(7); 17.

11. Bhattacharjee, I., Chatterjee, S. K., Chatterjee, S., \& Chandra, G. (2006). Antibacterial potentiality of Argemone mexicana solvent extracts against some pathogenic bacteria. Memórias do Instituto Oswaldo Cruz, 101(6), 645-648.

12. Mukharjee, P. K. (2002). Quality control of herbal drugs- and approach to evaluation of botanicals $31^{\text {st }}$ edition. New Delhi, Business Horizons Pharmaceuticals. Publications; 183-197.

13. Khandelwal, K.R. (1996). Practical Pharmacognosy. $3^{\text {rd }}$ edition. Pune: Nirali Prakashan, 165.

14. Himesh, S., Govind, N., Patel, S.S., Mishra, K., \& Singhai, A.K. (2011). Pharmacognostic studies of the Leaves of Syzgium cumini Linn. Int. Journal of Research in Pharmaceutical and Biomedical Sciences, 2(2), Apr-Jun, 1-3.

15. Himesh, S., Sita, S.P., Mishra, K., Govind, N., Singhai, A. K., Pathak, A.K. (2011). Preliminary pharmacognostical and phytochemical investigation of Tamarindus indica L.seed. Int. J. Res. Phytochem. Pharmacol, 1(2), 1-5.

16. Soni, H., Nayak, G., Mishra, K., Singahi, A. K., \& Pathak, A. K. (2010). Pharmacognostic and Phytochemical Evalution of Leaves of Coleus aromaticus. International Journal of Pharmacology and Biological Sciences, 4(4), 71.

17. Harborne, J.B. (1998). Phytochemical methods. $3^{\text {rd }}$ edition. London: Chapman and Hall, 5-7.

18. Stills, W.C., Kahn, M., Mitra, A. (1978). Rapid chromatographic techniques for preparative separation with modern resolution. Pharmacognosy Reviews, 1, 180-184. 